\title{
URINARY EXCRETION OF ACID POLYSACCHARIDE IN RHEUMATOID ARTHRITIS AND OTHER DISEASES
}

\author{
BY \\ G. LOEWI \\ Rheumatism Research Unit (M.R.C.), Canadian Red Cross Memorial Hospital, Taplow, Berks.
}

The excretion of acid mucopolysaccharide in the urine was described by Kerby (1954), using a method devised by Astrup (1947) for the estimation of heparin. Scott (1955) introduced the precipitation of acid mucopolysaccharides by quaternary ammonium salts; this method was adapted to urine by Di Ferrante and Rich (1956a, b). Di Ferrante (1957) found that patients with rheumatoid arthritis showed increased excretion of acid mucopolysaccharide when compared with normal controls. Di Ferrante, Robbins, and Rich (1957) described similar excess excretion in cases of disseminated lupus erythematosus. It was concluded (Rich, Di Ferrante, and Archibald, 1957) that "the urinary excretion of acid polysaccharide is elevated in several diseases associated with abnormal metabolism of mucopolysaccharide-rich connective tissues". It was therefore decided to compare the excretion of acid mucopolysaccharide in patients with rheumatoid arthritis with that in patients suffering from various other maladies, and to define, by isolation of the material, the type of acid polysaccharide in each particular specimen of urine, in order to explore possible differences and to give some idea of the origin of the material. Pooled samples were collected for more extensive analysis.

\section{Materials and Methods}

24-hour samples of urine were collected from patients in hospital. Most of the patients with rheumatoid arthritis had clinically active disease and a raised erythrocyte sedimentation rate, and the majority of the adult patients had a positive Rose-Waaler test. The urines were kept, without preservative, at $4^{\circ} \mathrm{C} .500 \mathrm{ml}$. urine was used for each estimation.

The method used for the isolation of acid mucopolysaccharide was similar to the modification by Meyer, Grumbach, Linker, and Hoffman (1958) of the method of Di Ferrante and Rich (1956b). Samples with a specific gravity of 1,020 or more were diluted with an equal volume of water. The urine was filtered and acidified to $\mathrm{pH} 6.0$ and a warm aqueous 5 per cent. solution of cetyl trimethylammonium bromide was added $(1.7 \mathrm{ml} . / 100 \mathrm{ml}$. urine). After standing overnight at $4^{\circ} \mathrm{C}$., the solution was centrifuged in the cold. The precipitate was washed three times in a large volume of ethanol. The material insoluble in ethanol was dissolved, with agitation and warming to $37^{\circ} \mathrm{C}$., in a small volume of 10 per cent. aqueous sodium acetate, and the pH was adjusted to $9 \cdot 0$. Insoluble material was centrifuged down and re-extracted with water. The combined supernatant was acidified to $\mathrm{pH} \mathbf{5 \cdot 0}$. The crude acid polysaccharide was then precipitated with 1.5 volumes of ethanol and left at $4^{\circ} \mathrm{C}$. overnight. This was centrifuged and the precipitate washed with 80 per cent. ethanol. It was extracted with a small volume of water and centrifuged at high speed. To the clear solution, calcium acetate and acetic acid were added to final concentrations of 5 per cent. and $0.5 \mathrm{~N}$, respectively. The solution was fractionally precipitated with alcohol, according to the method of Meyer, Davidson, Linker, and Hoffman (1956). Resulting fractions were washed in increasing concentrations of alcohol and dried in ether, and this was followed by desiccation over phosphorus pentoxide. Each sample was weighed and analysed for uronic acid both by the orcinol method and by Dische's carbazole method. All methods of analysis were as used by Loewi and Meyer (1958), and described by Meyer and others (1956) and Rapport, Meyer, and Linker (1951).

To obtain purified material for analysis, urine pools of about 10 l. were collected. After isolation by the above procedures, the material was dissolved in water and digested with pepsin for $24 \mathrm{hrs}$, followed by trypsin for a similar period. The material was reprecipitated and subjected to the procedure of Sevag (1934). After another precipitation, treatment with kaolin and Lloyd's reagent was carried out, and finally Dowex $50\left(\mathrm{H}^{+}\right)$was used. The method is essentially that used by Meyer and others (1956). 


\section{Results}

Table I shows the results of estimations of acid mucopolysaccharide in the urines of 73 individuals. Since the carbazole values differed somewhat from sample to sample, the amounts of polysaccharide found were adjusted by calculation to a carbazole value of 20 per cent. in each case, so that comparison could be made. The actual readings were nearly all close to this figure. In all cases, rheumatoid and others, acid polysaccharide was precipitated at between 40 and 50 per cent. ethanol concentration, and gave a ratio of carbazole to orcinol close to $1 \cdot 0$, indicating chondroitin sulphate $\mathrm{A}$ or $\mathrm{C}$. Though some adult cases of rheumatoid arthritis showed high excretion values, others showed values similar to those found in other diseases and in normal controls. The difference between female rheumatoid arthritics and normal controls approached significance $(P=<0 \cdot 10,>0 \cdot 05)$. Eight cases showed a daily excretion of more than $19 \mathrm{mg}$. acid mucopolysaccharide. These included four cases of rheumatoid arthritis, one of which was complicated by pyelo-nephritis, three cases of epilepsy, and one of pneumonia. Excretion of less than $1 \mathrm{mg}$. $24 \mathrm{hrs}$ was seen in two cases of rheumatoid arthritis complicated by amyloidosis. In the children studied, excretion of acid polysaccharide in rheumatoid arthritis was similar to that occurring in other diseases, but significantly lower than that found in normal controls $(P=0 \cdot 01)$. The figure taken for any particular patient was the first one obtained after admission, though, in most cases, several estimations were made subsequently. In two patients, in each of whom daily estimations were $\stackrel{\mathbb{C}}{\mathscr{C}}$ done on six consecutive days, the day-to-day 3 variations were found to be relatively small $(3.1 \mathrm{mg}$. 므.

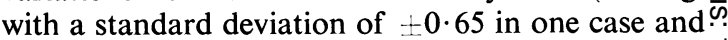
$12.4 \mathrm{mg}$. with S.D. $\pm 2 \cdot 38$ in the other). The $\overrightarrow{\vec{F}}$ majority of the figures were lower than those ob- $-\frac{?}{6}$ tained by Di Ferrante (1957); the reason for this may be sought in differences in the techniques used, since, in the present investigation, it was decided to $\overrightarrow{\mathbb{D}}$ sacrifice completeness of recovery to removal, as far as possible, of non-acid mucopolysaccharide material. Using the almost identical method, $\overrightarrow{0}$ Meyer and others (1958) obtained figures for normal $\overrightarrow{-}$ controls which are similar to those reported here. $\vec{\omega}$

Table II shows figures for acid mucopolysaccharide excretion in four patients before and during? salicylate administration. In two cases a fall was $\vec{\circ}$ recorded, while in one (Case 4) a rise in excretionc

$$
\text { TABLE II }
$$

EFFECT OF ADMINISTRATION OF SALICYLATES ON EXCRETION OF ACID MUCOPOLYSACCHARIDE (APS) INCS FOUR CASES OF RHEUMATOID ARTHRITIS

\begin{tabular}{|c|c|c|c|}
\hline \multirow{2}{*}{$\begin{array}{l}\text { Case } \\
\text { No. }\end{array}$} & \multicolumn{2}{|c|}{ APS (mg./24 hrs) } & \multirow{3}{*}{$\begin{array}{c}\text { Change while } \\
\text { taking Salicylates } \\
\begin{array}{c}\text { Fall followed } \\
\text { Rise }\end{array}\end{array}$} \\
\hline & $\begin{array}{l}\text { Control } \\
\text { Period }\end{array}$ & $\begin{array}{c}\text { Salicylate } \\
\text { (4-5 g./day) }\end{array}$ & \\
\hline 1 & $8 \cdot 7 ; 9 \cdot 0$ & $\begin{array}{l}3 \cdot 5 ; 3 \cdot 8 ; 2 \cdot 6 \\
2 \cdot 2 ; 3 \cdot 1 ; 3 \cdot 0\end{array}$ & \\
\hline 2 & $25 \cdot 4 ; 21 \cdot 3$ & $12 \cdot 3 ; 9 \cdot 4$ & Fall \\
\hline 3 & $9 \cdot 3 ; 10 \cdot 2$ & $14 \cdot 2 ; 2 \cdot 0$ & Fall \\
\hline 4 & $5 \cdot 6 ; 6 \cdot 3$ & $12 \cdot 0 ; 17 \cdot 9$ & Rise \\
\hline
\end{tabular}

TABLE I

MEAN URINARY EXCRETION OF ACID MUCOPOLYSACCHARIDE (APS) IN CHILDREN AND ADULTS WITH VARIOUS DISORDERS (mg./24 hrs, 20 per cent. Carbazole)

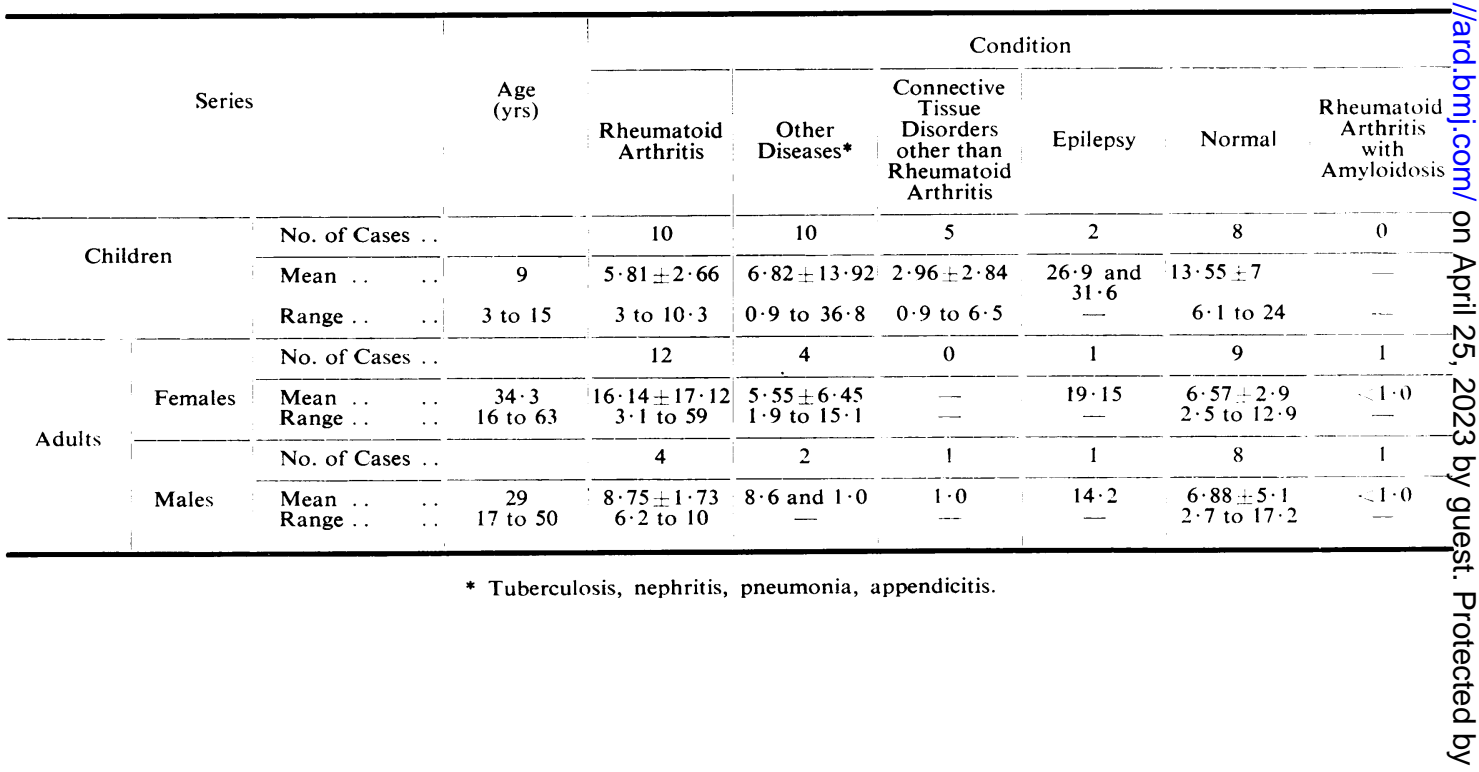


occurred, although this patient's temperature became normal and the erythrocyte sedimentation rate was falling during the administration of salicylate. Case 3 showed an initial rise, followed by a fall in acid polysaccharide excretion.

The purified acid polysaccharide obtained from large volumes of normal and rheumatoid urine was analysed (Table III). Precipitation by ethanol began at 40 per cent., and was complete at 50 per cent. In the two purified samples cited in Table III, the only amino-sugar found chromatographically was galactosamine, suggesting a chondroitin sulphate. When, however, less highly purified material was subjected to this procedure, a weak glucosamine spot was also obtained. This suggests a relatively small amount of hyaluronic acid or of keratosulphate, but the presence of some glucosaminecontaining protein cannot be excluded. The high Dische (carbazole) to orcinol ratio is indicative of chondroitin sulphate $\mathrm{A}$ or $\mathrm{C}$; rotational values are suggestive of chondroitin sulphate $\mathrm{C}$ and digestion by testicular hyaluronidase (reductimetric method, 24-hr incubation) also suggests chondroitin sulphate A or $\mathrm{C}$ rather than $\mathrm{B}$, since the latter is not hydrolysed by this enzyme. That the substance is not chondroitin sulphate $B$ is further shown by the relatively high ethanol solubility, the high ratio of Dische to orcinol value (chondroitin sulphate $B$ gives a ratio of around 0.5 ) and the low rotation. Precipitation at 40-50 per cent. ethanol and the rotation figures are suggestive of chondroitin sulphate $C$ rather than $A$. In the absence, however, of an infra-red pattern and of material sufficiently pure for this investigation to be carried out, such differentiation between chondroitin sulphate $\mathrm{A}$ and $\mathrm{C}$ cannot be made with any degree of assurance.

\section{Discussion}

This investigation was undertaken first to determine the exact nature of the acid polysaccharide excreted in rheumatoid arthritis and other diseases, and, secondly, to discover whether the increased excretion, as reported by Di Ferrante (1957), was peculiar to rheumatoid arthritis or was also encountered in unrelated diseases.

The same type of chondroitin sulphate was discovered in all specimens of urine examined in this investigation and the full analysis of pooled material reported in Table III confirmed this. Di Ferrante and Rich (1956a) showed that normal urine contained chondroitin sulphate A or C, and Di Ferrante (1957) indicated that the material obtained from pooled rheumatoid urine was similar, and could be depolymerized by hyaluronidase. Di Ferrante (1957) also reported the presence of some hyaluronic acid in the urinary acid polysaccharide. I have found no evidence of this in the purified material. A trace of glucosamine was found, however, when less highly purified material was examined. Urine from a case of Marfan's syndrome (personal observation) showed no abnormal constituents qualitatively or quantitatively. Material isolated in the present investigation from patients with epilepsy who were taking hydantoin proved to be, as in the rheumatoid and normal cases, chondroitin sulphate A or C.

With regard to the origin of this urinary constituent, Kerby (1954) showed that acid mucopolysaccharide was present in urine in the renal pelvis and that the urinary content was not raised by prostatic massage. Badin, Schubert, and Vouras (1955) obtained evidence of the presence in increased amount of a similar substance in plasma from cases of rheumatoid arthritis. One may assume, therefore, that urinary chondroitin sulphate is derived from plasma by renal excretion. Meyer (1957), discussing the distribution of acid mucopolysaccharides in various tissues, lists chondroitin sulphate $\mathrm{A}$ and/or $\mathrm{C}$ as occurring in cartilage and bone. These two tissues must, therefore, be considered as possible sites of origin of the urinary acid mucopolysaccharide, and both cartilage destruction and osteoporosis are indeed found in rheumatoid arthritis. It was noticed, however, that

TABLE III

ANALYTICAL DATA FOR URINARY ACID MUCOPOLYSACCHARIDE

\begin{tabular}{|c|c|c|c|c|c|c|c|c|}
\hline & Urine & \multirow{2}{*}{$\begin{array}{c}\mathrm{N} \\
\text { (per } \\
\text { cent.) }\end{array}$} & \multicolumn{2}{|c|}{ Hexosamine } & \multicolumn{2}{|c|}{$\begin{array}{l}\text { Uronic Acid } \\
\text { (per cent.) }\end{array}$} & \multirow{2}{*}[\alpha]{$^{D}$} & \multirow{2}{*}{$\begin{array}{c}\text { Digestion } \\
\text { with } \\
\text { Testicular } \\
\text { Hyaluronidase }\end{array}$} \\
\hline Source & Amount (mg.) & & $\begin{array}{c}\text { Per } \\
\text { cent. }\end{array}$ & Type & Orcinol & Dische & & \\
\hline Rheumatoid Arthritis & $28 \cdot 0(50 \text { per cent. Ethanol })^{*}$ & $3 \cdot 5$ & $20 \cdot 8$ & Galactosamine & $18 \cdot 6$ & $28 \cdot 6$ & $-5^{\circ}$ & + \\
\hline Normal & $16 \cdot 5(50 \text { per cent. Ethanol })^{*}$ & $-\dagger$ & $21 \cdot 0$ & Galactosamine & $18 \cdot 0$ & $29 \cdot 1$ & $-17^{\circ}$ & + \\
\hline
\end{tabular}

* Percentage at which precipitate obtained.

$\dagger$ Inadequate material for estimation 
cases of rheumatoid arthritis with extensive osteoporosis and a case of Cushing's disease did not have an unduly great excretion. Similarly, activity of the disease did not correlate with the amount of acid mucopolysaccharide excreted. It is also not possible to account on such a basis for the relatively high levels of excretion shown by some epileptics.

When the quantitative excretion figures were examined, much overlap was found between rheumatoid arthritics, patients with other diseases, and normal controls. Owing to the very wide ranges of readings in each of these categories, no statistically significant differences were found. The reason for these wide variations is apparently not to be sought in the techniques employed, since repeated readings on single patients did not show such variations. Several of the adult patients with rheumatoid arthritis excreted abnormally large amounts of acid polysaccharide, while others excreted only small amounts. The distribution showed no constant relationship to activity of the disease, as assessed by the erythrocyte sedimentation rate. Many of the patients were receiving salicylates and other forms of treatment, which may have caused a decrease in the amount excreted; Di Ferrante (1957) observed such an effect, and a fall occurred in three out of four patients on salicylates, as recorded in Table II. There were, however, some patients who showed a low excretion in the absence of drug therapy. The low level of excretion of acid polysaccharide in children with rheumatoid arthritis may be the result of interference with skeletal growth. Such an explanation is also suggested by the significantly greater excretion in normal children when compared with normal adults $(P=<0 \cdot 02$, $>0.01)$. This latter finding was also noted by Rich and others (1957). Relatively high excretion was found in cases of epilepsy receiving hydantoin and in a case of pneumonia (normal controls of comparable age showed much lower excretion). In two cases of rheumatoid arthritis complicated by extensive amyloidosis involving the kidneys, excretion of acid polysaccharide was particularly low. Craddock and Kerby (1955) found decreased excretion in cases of diabetes with renal complications. Patients with other disorders involving connective tissue, such as rheumatic fever and dermatomyositis, did not show high urinary acid polysaccharide excretion. Di Ferrante and others (1957) reported a raised level of excretion in disseminated lupus erythematosus. The failure to demonstrate a high level of acid polysaccharide excretion in many cases of rheumatoid arthritis, although the disease was active, and failure to demonstrate raised levels in some other connective tissue disorders, suggest that the statement by Rich and others (1957) that "the urinary excretion of acid polysaccharide is elevated in several diseases associated with abnormal metabolism of mucopolysaccharide-rich connective tissues" needs qualification. The results of the present investigation? do not suggest that urinary acid polysaccharide $\frac{\overline{ }}{\bar{*}}$ excretion constantly mirrors any such abnormality $\frac{\bar{D}}{\vec{D}}$ in the tissues, such as might occur in the rheumatic $\underset{\varrho}{\varnothing}$ diseases. To date, evidence for such a disorder has only been found in gargoylism, which shows high $\rightarrow$

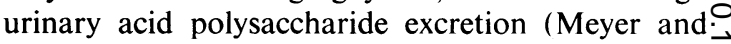
others, 1958).

\section{Summary}

Acid mucopolysaccharide has been estimated $\stackrel{\overrightarrow{2}}{\overrightarrow{0}}$ in the urine of patients with rheumatoid arthritis $\vec{\infty}$ and with other diseases, and in normal controls. $\omega$ A raised level of excretion was found in some adult patients with rheumatoid arthritis, while otherso showed normal or low levels. No rise was found in patients with rheumatic fever and dermatomyositis, $\vec{\infty}$ but a few patients with other diseases showed raised $\frac{\mathbb{D}}{O}$ levels of excretion. In children, the excretion was $\mathbb{\mathbb { D }}$ less in rheumatoid arthritics than in normal controls.

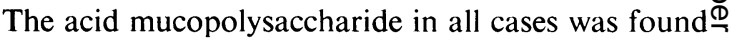
to be chondroitin sulphate $\mathrm{A}$ or $\mathrm{C}$.

\section{REFERENCES}

Astrup. P. (1947). Acta pharmacol. (Kbh.), 3, 165

Badin, J., Schubert, M., and Vouras, M. (1955). J. clin. Invest 34, 1317.

Craddock, J. G., and Kerby, G. P. (1955) J. Lab. clin. Med.. 46, 193 Di Ferrante, N. (1957). J. clin. Invest., 36, 1516. and Rich, C. (1956a). Clin. chim. Acta, 1519 (1956b). J. Lab. clin. Med., 48, 491. Robbins, W. C., and Rich, C. (1957). Ibid., 50, 897

Kerby, G. P. (1954). J. clin Invest., 33, 1168.

Loewi, G. and Meyer, K. (1958). Biochim. biophys. Acta, 27. 453 윽 Meyer, K. (1957). Harvev Lect., 1955-1956, 51, 88.

$\longrightarrow$, Davidson, E., Linker, A., and Hoffman. P. (1956). Biochim. biophws. Acta, 21, 506 .

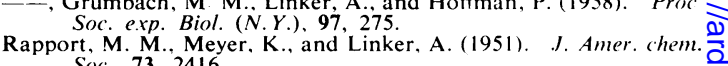
Soc., 73, 2416.

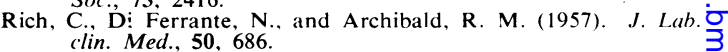

Scott, J. E. (1955). Chem. and Ind., p. 168

Sevag, M. G. (1934). Biochem. Z., 273, 419.

Excrétion urinaire de polysaccharide acide dans l'arthrite rhumatismale et dans d'autres maladies RÉSUMÉ

On détermina le mucopolysaccharide acide chez des malades atteints d'arthrite rhumatismale et d'autres or affections, ainsi que chez des témoins. On en trouva un N taux élevé chez quelques adultes atteints d'arthrite rhumatismale, mais chez d'autres ce taux fut normal ouw bas. On ne trouva pas de taux augmentés chez des malades atteints de rhumatisme articulaire aigu ou de dermatomyosite, mais on les observa chez quelques autres malades. Chez des enfants rhumatisants arth- $\mathbb{E}$ ritiques il y eut une diminution du taux, absente chez ${ }^{+}$ des enfants normaux. Dans tous les cas on identifia 
le mucopolysaccharide acide comme sulfate de chondroïtine A ou C.

\section{Excreción urinaria de polisacarido ácido en la artritis reumatoide y otras enfermedades}

\section{SUMARIO}

Se determinó el mucopolisacarido ácido en la orina de enfermos con artritis reumatoide, con otras enfer- medades y en la de testigos. Se halló una tasa elevada en algunos adultos con atritis reumatoide, pero en otros ésta fué normal o baja. No hubo aumento en enfermos con reumatismo poliarticular agudo o con dermatomiositis, pero se observó una tasa aumentada en algunos otros enfermos. En niños reumatoideo-artriticos la excreción fué disminuida en comparación con la de niños normales. En todos los casos se identificó el mucopolisacarido ácido como sulfato de condroitina A o C. 